\title{
Employers' Perception of the Role of Technical Vocational Education and Training in Sustainable Development in Nigeria
}

\author{
Abubakar Sadiq BAPPAH ${ }^{1}$, Jimritu Dunama MEDUGU ${ }^{2}$ \\ ${ }^{I}$ Vocational and Technology Education Programme, school of technology education, Abubakar Tafawa Balewa \\ University Bauchi \\ ${ }^{2}$ Department of Electrical Technology Education, School of Technology and Science Education, \\ Modibbo Adama University of Technology, Yola
}

\begin{abstract}
The study was aimed at finding out the opinions of employers of labour on the roles of Technical Vocational Education and Training (TVET) for sustainable development in Nigeria. The sample comprised of 84 indigenous and 72 multinational employers in the North-East Geopolitical Zone of Nigeria. The study was guided by two research questions and two null hypotheses. A duly validated 17-item 5 - point likert scale questionnaire was used for data collection. Data were analyzed using means and standard deviation and the ttest to test the hypotheses at 0.05 level of significance. The findings revealed among other things that, both indigenous and multi-national employers were not satisfied with the contribution of TVET for sustainable development in Nigeria. Based on the findings, implications were deduced, relevant recommendations were highlighted and conclusion was drawn.
\end{abstract}

Key words: Employers, Technical Vocational Education, Training, Indigenous employers, Multi-national employers

\section{Introduction}

The economic competitiveness of a country depends on the skills of its workforce. The skills and the competencies of the workforce, in turn, are dependent upon the quality of the country's education and training system [1]. Furthermore, [2] posits that education is undisputedly recognized as the bedrock of any meaningful development while Technical Vocational Education and Training (TVET) is the cornerstone for any sustainable technological development programme. Thus, TVET is regarded as workforce education particularly, in its traditional role, facilitates the adjustment of the skills and knowledge of man to the changing demands within the society. This form of education is deliberately designed to help man improve his skills. It places emphasis on skill development of the individuals in chosen occupations [3]. TVET therefore, has an important role to play in raising the quality of work and quality of TVET graduates, increasing job satisfaction and motivating workers as well as enhancing productivity [4]. In the new economic environment therefore, TVET is expected to produce an educated, skilled and motivated work force.

The socio-economic changes currently taking place worldwide poses challenges to educational and industrial sectors. This trend has given rise to economic, political and social crises that are threatening the political and economic stability of some nations. In this regard, [5] stated that, the rising unemployment, lack of skilled workers, high dropout rates and the changing demographic nature of the workforce have placed the issue of workforce education high on the educational reform agenda of many nations. In line with this view, [6] observed that the massive rate of unemployment and the changing face of the economic, social, political and labour market worldwide have led to new education reforms/polices with emphasis on TVET geared towards helping the youths and adults to be self-reliant.

It is re-organization of the changing role of TVET in the world economic order that different countries have come up with different framework towards repositioning their TVET programmes. According to [7], the French National Assembly approved the law on social modernization which contains important measures concerning TVET and the right to employment. Michael further discussed the modernization of training places and strengthening their practical element with emphasis on social and practical skills development. In Germany, one of the objectives of the country's education reform is to promote the vocational education of gifted young people and to raise the standard of TVET [7].

In Kenya, the 8-4-4 educational system was introduced with emphasis on TVET which ensured that the graduate students at every level have some scientific and practical knowledge that can be utilized for self employment, salaried employment or further training [8]. Nigeria is also among the League of Nations revamping her TVET programmes which was introduced into the 6-3-3-4 educational system in 1982 [9].

Despite the importance of TVET in the economic development, of any nation, people still have different perspectives about the programme goals. International comparison shows that employers in the United States of America and United Kingdom believe that the present state of TVET in their respective countries is 
inadequate to train students effectively for the changing demands of the work place [10] \& [11]. Australian employers however, are reported as being satisfied with their TVET system [12]. Also, Malaysian employers and educators, expressed satisfaction over the contribution of TVE to the economic development of Malaysia [1]. These evidences were obtained from studies carried out in Europe, America and Asia. Therefore, the problem of this study, posed as a question is: what are the perceptions of employers on the role of TVET for sustainable development in Nigeria?

\subsection{Purpose of the Study}

The purpose of this study is to investigate the perceptions of employers regarding the role of TVET in sustainable development in Nigeria. Specifically the study intends to:

1. Investigate the perceptions of employers regarding the contributions of TVET to the sustainable development of Nigeria.

2. Find out the perceptions of employers regarding the employability of graduates of TVE programmes.

\subsection{Research Questions}

The following research questions guided the study:

1. What are the perceptions of employers regarding the contribution of TVET to the sustainable development of Nigeria?

2. What are the perceptions of employer regarding the employability of graduates of TVET programmes?

\subsection{Hypotheses}

The following two null hypotheses were tested at 0.05 level of confidence.

$\mathrm{Ho}_{1}$ There is no significant difference between mean responses of indigenous and multinational employers regarding the contribution of TVET to the sustainable development of Nigeria.

$\mathrm{Ho}_{2}$ There is no significant different between the mean responses of indigenous and multi-nationals employers regarding the employability of graduates of TVET programme.

\section{Methodology}

The study used a descriptive survey design. According to Borg and Gall (1996), descriptive research involves providing careful descriptions of a phenomenon. Its purpose is to generate accurate description of an event, attitude or behaviour. The study was carried out in North-East Geopolitical Zone of Nigeria comprising Adamawa, Borno, Bauchi, Gombe, Taraba and Yobe States. The choice of this area was informed by the concentration of medium and large scale industries involved in the divergent technological processes as the mainstream of Nigerian economy.

A pilot study carried out to determine the number of industries relevant to this study revealed a total of 57 industries (31 indigenous and 26 multinationals). These industries were limited to the categories of oil and gas equipment servicing, electrical engineering services, metallurgical and plastic products, machinery manufacturing, earth and cement industries.

The industrial categories were chosen based on the assumption that the majority of TVET graduates were employed in these industries. The corporate management personnel of these industries constituted the population of the study. The entire population was used as sample for the study because the number is few. In each of the industry three management staff (personnel managers, production/technical managers and supervisors) was requested to complete the survey, for a total sample of 171 employers, (93 indigenous and 78 multi-nationals). These management personnel were assumed to have regular contact with the employees. As such, they were in a unique position to evaluate the employees.

\section{Data Collection and Analysis Techniques}

A total of 171 copies of TVETRSDQ were administered directly to the respondent's by the researcher and five assistants. Each copy of the instrument was accompanied with a introductory letter requesting for cooperation. A total of 156 instruments (84 indigenous employers' instruments and 72 multinational employers' instruments) were duly completed and returned. Thus a return rate of $91 \%$ was obtained.

Descriptive and inferential statistics ware used to organize, analysis and interpreter the data. Mean and Standard deviation were the descriptive statistics used to answer the research questions posed in the study. Each TVETRSDQ item was accepted as "Agree", if mean value is greater than or equal to 3.50 where mean value is equal to 2.50 but less than 3.50 , the TVETRSDQ item was regarded as "undecided". A TVETRSDQ item was regarded as "Disagree" if mean value is less than 2.50. T-test inferential statistics for large independent samples where $\mathrm{N}$ is greater than 30 , as suggested by [13] and [14], was used to test the hypotheses in this study. 
IV.1 Research Question 1

\section{Results}

What are employers' perceptions regarding the contribution of TVET to the sustainable development of Nigeria?

Table 1: Mean Ratings and Standard Deviation of Respondents on the Contribution of TVET to Sustainable Development

\begin{tabular}{|l|l|l|l|l|}
\hline S/No & \multicolumn{1}{|c|}{ Item } & $\overline{\mathbf{X}}$ & $\mathbf{S D}$ & Decision \\
\hline 1. & $\begin{array}{l}\text { TVET institutions have prepared sufficient skilled workers to satisfy the needs } \\
\text { of Nigeria's work force }\end{array}$ & 2.45 & 1.19 & Disagree \\
\hline 2. & $\begin{array}{l}\text { TVET institutions have prepared sufficient semi-skilled workers to satisfy the } \\
\text { needs of Nigeria's workforce }\end{array}$ & 2.37 & 1.19 & Disagree \\
\hline 3. & $\begin{array}{l}\text { TVET institutions are more suitable than regular academic school programmes } \\
\text { in responding to the rapidly changing nature of skills }\end{array}$ & 3.17 & 1.32 & Undecided \\
\hline 4. & $\begin{array}{l}\text { TVET institution are more suitable than regular academic school programmes } \\
\text { in responding to new technology }\end{array}$ & 3.20 & 1.33 & Undecided \\
\hline 5. & TVET has reduced unemployment rate in Nigeria & 2.00 & 1.21 & Disagree \\
\hline 6. & TVET has reduced youth restiveness in Nigeria & 2.56 & 1.21 & Undecided \\
\hline & Grand Mean & $\mathbf{2 . 6 3}$ & & \\
\hline
\end{tabular}

The results on table 1 shows that the respondents were undecided with items 3,4 and 6 , with mean ratings of $3.17(\mathrm{SD}=1.32), 3.20(\mathrm{SD}=1.33)$ and $2.56(\mathrm{SD}=1.21)$ respectively. They disagreed with items 1,2 and 5 with mean ratings and standard deviations of $2.45(\mathrm{SD}=1.19), 2.37(\mathrm{SD}=1.19)$ and $2.00(\mathrm{SD}=1.21)$ with a grand mean of 2.63 respectively. The result shows that employers have a negative perception of the contribution of TVET to the sustainable development of Nigeria.

\section{IV.2 Research Question 2}

What are the perceptions of employers regarding the employability of graduates of TVET programmes?

Table 2: Mean Ratings and Standard Deviation of Respondents on the Employability of TVET Graduates.

\begin{tabular}{|l|l|r|l|l|}
\hline S/No & \multicolumn{1}{|l|}{ Item } & $\overline{\mathbf{X}}$ & SD & Decision \\
\hline 7. & TVET graduates are well prepared to enter the competitive workforce & 2.19 & 1.15 & Disagree \\
\hline 8. & TVET graduates possess necessary technical skill in their specialization & 2.21 & 1.12 & Disagree \\
\hline 9. & TVET graduates are well prepared to be self reliant & 1.86 & 0.73 & Disagree \\
\hline 10. & $\begin{array}{l}\text { TVET graduates have better employment opportunities than graduates from } \\
\text { academic secondary school }\end{array}$ & 3.13 & 1.24 & Undecided \\
\hline 11. & TVET graduates are self motivated & 3.82 & 1.07 & Agree \\
\hline 12. & TVET graduates possess necessary social and interposal skills & 3.30 & 1.12 & Undecided \\
\hline 13. & TVET graduates poses necessary communication skills & 3.56 & 173 & Agree \\
\hline 14. & TVET graduates have entrepreneurial skills & 2.25 & 1.15 & Disagree \\
\hline 15. & TVET graduates posses good attitudes toward work & 3.67 & 1.19 & Agree \\
\hline 16. & TVET graduates possess necessary critical thinking skills & 3.24 & 1.26 & Undecided \\
\hline 17. & TVET graduates possess necessary problem - solving skills & 3.06 & 1.33 & Undecided \\
\hline & Grand Mean & $\mathbf{2 . 9 4}$ & & \\
\hline
\end{tabular}

In Table 2, the respondents agreed with items $11(X=3.82, \mathrm{SD}=1.07)$ and item $15(\mathrm{X}=3.67, \mathrm{SD}=1.19)$. They were undecided on four items, namely; items $10,12,16,17$ with mean ratings and standard deviation of 3.13 $(\mathrm{SD}=1.24) 3.30(\mathrm{SD}=1.12), 3.23(\mathrm{SD}=1.26)$ and $3.06(\mathrm{SD}=1.33)$ respectively. Finally, the respondents disagreed with four items, $7,8,9$ and 14 with mean ratings of $2.19(\mathrm{SD}=1.15), 2.21(\mathrm{SD}=1.12), 1.86(\mathrm{SD}=$ $0.73)$ and $2.25(\mathrm{SD}=1.15)$. The grand mean of 2.94 indicates that the respondents generally have unfavourable perception on the employability of TVET graduates in Nigeria.

$\mathrm{Ho}_{1}$ There is no significant difference between the mean responses of indigenous and multinational employers regarding the contribution of TVET to the sustainable development of Nigeria. 
Table 3: t-Test Analysis of the Response of Indigenous and Multi-national Employers Regarding TVET Contribution to Sustainable Development

\begin{tabular}{|l|l|l|l|l|l|l|l|l|}
\hline Variable & $\mathrm{N}$ & $\boldsymbol{\mathrm { X }}$ & $\mathrm{SD}$ & $\alpha$ & $\mathrm{df}$ & $\mathrm{t}-\mathrm{cal}$ & $\mathrm{t}$-crit & Decision \\
\hline $\begin{array}{l}\text { Indigenous } \\
\text { Employer }\end{array}$ & 84 & 2.70 & 1.29 & 0.05 & 154 & 0.81 & 1.96 & Not Significant \\
\cline { 1 - 5 } $\begin{array}{l}\text { Multinational } \\
\text { Employer }\end{array}$ & 72 & 2.54 & 1.18 & & & & & \\
\hline
\end{tabular}

Table 3 show that 84 indigenous employers had a mean ratings of $2.70(\mathrm{SD}=1.29)$ while the 72 multi-national employers had a mean rating of $2.54(\mathrm{SD}=1.18$ ) yielding a calculated $\mathrm{t}$-value of 0.81 . Since the calculated $\mathrm{t}-$ value $(0.81)$ is less than critical $\mathrm{t}$-value (1.96) at $\mathrm{df}=154$ and 0.05 level of confidence, the null hypothesis was therefore, not rejected. Finally, the result is that there is no significant different in the opinion of indigenous and multi-national employers regarding the contribution of TVET to sustainable development in Nigeria.

$\mathrm{Ho}_{2}$-There is no significant difference between the mean responses of indigenous and multinational employers regarding the employability of graduates of TVET programme.

Table 4: t-Test Analysis of the Response of Indigenous and Multi-national Employers Regarding TVET Contribution to Sustainable Development

\begin{tabular}{|l|l|l|l|l|l|l|l|l|}
\hline Variable & $\mathrm{N}$ & $\mathrm{X}$ & $\mathrm{SD}$ & $\alpha$ & $\mathrm{df}$ & $\mathrm{t}$-cal & $\mathrm{t}$-crit & Decision \\
\hline $\begin{array}{l}\text { Indigenous } \\
\text { Employer }\end{array}$ & 84 & 3.01 & 1.23 & 0.05 & 154 & 0.84 & 1.96 & Not Significant \\
\cline { 1 - 4 } \\
$\begin{array}{l}\text { Multoyer } \\
\text { Employer }\end{array}$ & 72 & 2.85 & 1.13 & & & & & \\
\hline
\end{tabular}

Table 4 reveals that 84 indigenous employers had a mean rating of $3.01(\mathrm{SD}=1.23)$ and the 72 multi-national employers a mean rating of 2.85 (1.13) yielding a calculated t-value of 0.84 . The calculated t-value of 0.84 is less than the critical t-value (1.96) at $\mathrm{df}=154$ and 0.05 level of significance. The second null hypothesis is therefore not rejected but accepted. The implication of this result is that both indigenous and multi-national employers hold the same negative opinion regarding employability of TVET graduates.

\section{Discussion}

From the data presented in Table 1, it is safe to conclude that Nigerian employers are not satisfied with the Technical and Vocational Education and Training (TVET) system in Nigeria. They maintain that the present TVET programmes have not prepared sufficient skilled and semi-skilled workers to satisfy the needs of Nigeria's workforce. This finding is consistent with the perception of U.S and UK employers [10] who believed that the state of TVET in their respective countries is inadequate to train students effectively for the changing demands of the work place. However, the findings negates [12], and [1] who reported that Australian and Malaysian employers respectively are satisfied with their TVET system. Furthermore, it was revealed that TVE has not reduced unemployment in the country. The implication of these findings is that there is an urgent demand on Federal Government and private sector to step up efforts to upgrade the quality of TVET in Nigeria.

In terms of the employability of TVET graduates, employers in Nigeria believed that TVET graduates are not well prepared to enter the competitive workplace and do not posses technical skills in their areas of specialization. These findings contradict the opinions of Malaysian employers [1] who believed that complete TVET programmes in their country posses more than adequate technical skills. Furthermore the respondents were not satisfied with entrepreneur skills of the TVET graduates. The state of these findings suggests that technical and entrepreneurship skills that could prepare the students to be relevant to the industries and become self-reliant should be fully integrated into TVET programmes.

\section{Conclusion}

The present study investigated the role of TVET for sustainable development in Nigeria as perceived by employers of labour. The study has revealed that for Nigeria to address the socio-economic and technological changes currently taking place thereby survive in the modern world, TVET in Nigeria must definitely take a new outlook in line with the global trend. 


\section{Recommendations}

Based on the foregoing, the following recommendations are offered:

1. The federal, state and local governments should provide a clear vision and mission for TVET in Nigeria.

2. The funding of TVET programmes should be increased.

3. Government can partner with the private sector to maintain and expand TVET programmes in Nigeria.

4. Government should provide effective leadership and incentives to the private sector to encourage partnership and collaboration with TVET institutions.

5. Government to establish more TVET institutions for the training of semiskilled and skilled personnel.

6. Youths to be encouraged through scholarship to enrol into TVET programmes.

7. A balanced approach should be emphasized in the school curriculum through the integration of technical employability and entrepreneurial skills in TVET.

8. Curriculum planners and implementers to enhance skill development strategies.

9. Government and allied Non governmental agencies to sustain and promote school-industry cooperation

\section{References}

[1] R. B.Mustapha and J.B Greeman. The role of vocational education in economic development of Malaysia: Educationists and employers Perspectives Journal of Industrial Teacher Education 3 9(2), 2002.

[2] O. Aina. Technical and Vocational Education (TVE) in Nigeria: the way forward. Paper presented at the ETF zonal sensitisation workshops on the importance of technical and vocational education in Nigeria, Port Harcourt, 2006

[3] S. O. Olaitan. Essential considerations for an effective vocational - technical education development in Nigeria. Paper presented at $8^{\text {th }}$ Annual conference of Nigerian vocational association at university of Uyo, Akwa Ibom State, 1993

[4] T.Manifred, and W. Jennifer. Vocational Education and Training: key To the Future. Greece: Colibri Ltd, 2004.

[5] H. Giroux. Series introduction: Reading work education as the practice theory. In R. I simon, D. Dippoo, \& A. Schenk (Eds.), Learning Work: A Critical Pedagogy of Work Education. New York: Bergin \& Ganvey, 1991

[6] C.C. Okolocha. Vocational technical education in Nigeria: Challenges and the way forward. Unizik Orient Journal of Education 2(1), 2006, 180- 189

[7] A. Michael. Development in the Field of Vocational Education and Training (VET) system of Brussels: member states European centre for the development of vocational training, 2002.

[8] Republic of Kenya. Ministry of Education, Science and technology: 8 - 4 system of Education Nairobi: Government printer, 1984

[9] Federal Republic of Nigeria. National Policy on Education (3ed) Yaba, Lagos NERC Press, 2004

[10] A. Brown and E.A. Keep. U K perspective on how well initial vocational education and training facilitates lifelong learning. Paper presented at the European conference on educational Research, Lahti Fin Land, 1999.

[11] J. A. Distler. Attitudes and perceptions of Maryland's Mid-shore employers torward vocational education and employment training programs. Unpublished doctorial dissertations Temple University, USA, 1992.

[12] P. Fairwealther. Employers perceptions of training and the way forward. In C. Robinson \& K. Arthy (Eds), Lifelong learning: Developing a Training Culture. Leabrook, South Australia: NCVER, 1999

[13] D.I. Denga. Educational Measurement, Continuous Assessment and Psychological Testing. Calabar, Nigeria: Rapid educational publisher limited, 1987.

[14] B.G. Nworgu. Educational Research: Basic Issues and methodology. Ibadan, Nigeria: Wisdom Publisher limited, 1991. 